\title{
Causes of Variation Order and the Impact on Project Cost Building in Sudirman
}

\author{
Caesarani Gloria Putri ${ }^{1}$, Erry Rimawan ${ }^{2}$, Lindra Aulia Rachman ${ }^{3}$, Prasetyo Madyo Utomo ${ }^{4}$ \\ ${ }^{1}$ Magister of Management, Mercu Buana University, Jakarta, Indonesia \\ 2,3,4 Magister of Industrial Engineering, Mercu Buana University, Jakarta, Indonesia
}

\begin{abstract}
Variation order on the construction project can negatively affect project implementation costs are swelling. This occurs due to the factors that cause variation work order. Data collection technique used observation and interview methods and then be made a factor analysis of causes and effects of variation order to the cost of implementation. These results indicate that the biggest factors causing variation work order is a design change with a percentage of $60 \%$, while the smallest is the causative factor prime cost rate with the percentage of $2 \%$ of the total number of jobs variation order. The impact on costs due to the variation of work orders amounted to $4.78 \%$ of the amount of the initial contract with the percentage of $34.85 \%$ work structures and architectural work for $65.15 \%$ of the total variation work order.
\end{abstract}

Keywords:- Variation order, construction, contract, cost, etc.

\section{INTRODUCTION}

Project construction is a temporary business that has a time limit of execution and budget and produce a product or service. The work of variation order or added work is less common in the implementation of construction projects. Variation order work is a form of refinement of existing designs in a contract work. Variation order due to change of plan by owner, material change from owner and design change by owner. In the application of variation order job claims, the contractor shall furnish the requirements documents in order for the claim to be received by the owner. The document is a recap of work variation orders, site intruction, minutes of meetings, quantity calculations, shop drawing, contracts, documentation. In the contract work between the contractor and the owner has arranged issues regarding changes and work variation order. Variation orders are written agreements signed by owners and contractors.

Planner to modify or give change to work which has been arranged in contract document. Where such changes may result in adjustments to the Cost and Time of the Implementation.

As happened in one of the Project Office Building Sudirman Central Business District. The project is experiencing cost overruns as a result of variation work order. The largest percentage of variation orders included work on the project is the kind of work structure and architecture.
This is the underlying writer take the topic of the variation order on the Project Office Building Sudirman Central Business District. By knowing the factors that cause variation orders and the impact on the cost of the project is expected to minimize and anticipate the variation work order. Based on the description of the background issues raised above, taken the problems that can be formulated as follows:

$>$ The largest percentage variation work order on the Project Office Building Sudirman Central Business District is a structural and architectural work.

$>$ The existence of various factors that cause the variation order on the Project Office Building Sudirman Central Business District.

$>$ Project Office Building Sudirman Central Business District are experiencing cost overruns as a result of variation work order.

The objectives of this research are:

$>$ Analyze how much percentage of the work structure and architecture in order variarion work Project Office Building Sudirman Central Business District.

$>$ Identify what are the factors that cause variation orders on the Project Office Building Sudirman Central Business District.

> Analyzing how big the impact of a variation order to the cost of the Project Office Building Sudirman Central Business District.

\section{LITERATURE}

Change order (Variation / change order) is a change in the scope of the contract, confirmation of the revised scheduling, collection of other modifications and in the form of a standard form that includes a summary of the description of the changes and the impact of such changes to the contract, both in time and cost of the project (Barrie \& Paulson, 1992).

Variation / change order to change the details and conditions of employment, resulting in the addition of jobs (Extra Work) or a reduction in employment. A formal request to the contractor by the project owner to do extra work because the contractor find errors (omissions) of the project owners or planners. Construction change according to (Fisk \& Reynolds, 2006), consisting of:

- The imperfection of the planning and specification

- Interpretation of the engineer different

- Standart higher performance than the specified 
- Impropriety inspection and rejection of

- Changes in the method of implementation of

- Changes in the circuit construction

- Things are not specified byproject owners

- The impossibility and impracticabilityin the implementation.

In order variation there are two basic kinds of change, namely the Direct Change or a change in formal and informal Contruction Change or alteration.

\section{Direct Change}

Direct change or formal changes are proposed changes in writing, proposed to the contractor to change the scope of work, execution time, costs or other things different that has been specified in the contract (Gilbreath, 1992).

\section{Constructive Change}

Constructive change is informal action to order a modification of the contract on the ground that occurs because of the request of the planner or contractor. Constructive Change is also described as an agreement between the owner and the contractor changes in terms of cost and time (Barrie \& Paulson, 1992), therefore, should the contractor should submit the changes in writing.

\section{METHODOLOGY}

Researchers used data collection based on primary data, secondary data and literature data. Collecting data using primary data in the form of observation. An observation method claims data variation made to order, so it can be retrieved analysis of causes of variation orders and the impact of variation in the order against the implementation of the project. An observation method is observation of variation orders against the contract. The contents of the contract procedures are in accordance with the implementation on the ground. So the analysis of observations of writing material. And using secondary data such as data projects, for example: a contract, shop drawings, minutes of meetings, and other data. Literature data can assist and compare the existing theories to the reality on the project.

The data collection of this thesis is as follows:

\section{$>$ Points Research}

Points research in this thesis is one of the Project Office Building located at the Sudirman Central Business District, South Jakarta.

\section{Time Research}

This research was conducted in July 2017 to October 2017 is divided into two stages:

- The first stage is conducted observations and interviews bertempatan at the project site development.

- The second stage is the stage of data processing which is a variation order of data where the research project.

\section{$>$ Data Collection Methods}

Data collection methods to be done to complete the final task of this manuscript there are two primary data and secondary data. Primary data and secondary data to complement this research are as follows:

\section{- Primary Data}

Primary data is data obtained directly from the subject of research as a source of information sought. Field observations are direct observation project to observe, see, record important information, and conduct a question and answer with the project (contractor) to obtain information and data about the project.

\section{- Secondary Data}

Secondary data is data obtained by the other party, not directly obtained by the researchers of the subject of research. Secondary data is generally tangible documentation data or data reports are already available. Secondary data in this thesis is derived from the data obtained that contains the project management of project data and the data of the project. Secondary data needed for this final task, among others, the data variation orders, contracts, and Site Instruction.

After getting the results of data collection techniques. The writer can process data and make analyzes. So the identification of factors causing variation orders and the impact of a variation order to the cost of the project can be analyzed and observation based methods research by the author.

Conclusions is the final step in this research that it relates to the goals to be achieved. Conclusion to get the factors causing variation orders and variation orders to get the amount of the amount of the type of work structure and architecture.

\section{ANALYSIS}

The study was conducted in the Office Building project Sudirman Central Business District, located on the road Tulodong Up, Kebayoran Baru. Type of project is the construction of an office building that will be used by the tenant. The building is constructed of 48 floors consisting of basement, podium and tower.

The contract, which is used in this project is the Development Contract with Fixed Price Per diems types. This contract type is where the contractor agreed to implement all of the scope of work that is offered in accordance with the conditions agreed with the total price of the entire work or the unit price of each kind of work has been set from the beginning. The contract amount to work and architectural structures contained in the Office Building project Sudirman Central Business District is Rp. $1,187,701,101,231$. 
The amount of variation orders that occur based Project Manager Instruction (PMI) is 53 work items with a total amount of Rp. 56,796,807,199. Here is a list of variation orders occur:

\begin{tabular}{|c|c|c|c|c|c|}
\hline No. & Description & $\begin{array}{l}\text { Amount } \\
\text { (Rupiah) }\end{array}$ & $\begin{array}{l}\text { Causative } \\
\text { Factor }\end{array}$ & Instructed by & Scope of Work \\
\hline 1 & $\begin{array}{c}\text { Supply and Installation of Starter Bars into the Existing } \\
\text { Dwalls }\end{array}$ & $3,856,614,187$ & Add. Works & Owner & Structure \\
\hline 2 & $\begin{array}{l}\text { Supply and Installation of Additional Rebars to Mat } \\
\text { Foundation }\end{array}$ & $147,963,652$ & Add. Works & Owner & Structure \\
\hline 3 & $\begin{array}{c}\text { Supply and Installation of Additional Rebars to } \\
\text { Basement } 6 \text { (B6) Slab due to misplacement } \\
\text { of Bored Pile P63 }\end{array}$ & $135,475,003$ & Add. Works & Consultants & Structure \\
\hline 4 & $\begin{array}{l}\text { Reinforced Concrete (RC) corbels, plinths, Beams and } \\
\text { Steel Hooks to Lift Machine Room at Level } 19\end{array}$ & $87,679,214$ & Design Change & Owner & Structure \\
\hline 5 & $\begin{array}{c}\text { Reinforced Concrete (RC) Work after Forcon Drawing } \\
\text { Issued on or before } 31 \text { December }\end{array}$ & $12,432,164,900$ & Design Change & Owner & Structure \\
\hline 6 & $\begin{array}{l}\text { Gypsum Ceiling to the perimeter at Curtain Box and } \\
\text { Corewall }\end{array}$ & $1,919,544,000$ & Add. Works & Owner & Architecture \\
\hline 7 & - Steel Grating at 42Floor Level & $2,972,884,947$ & Design Change & Consultants & Architecture \\
\hline 8 & Steel Stair Type P2 Ground Floor to 5th Floor & $162,628,705$ & Design Change & Owner & Structure \\
\hline 9 & $\begin{array}{l}\text { AdditionalFire Proofing from Ground Floor to 41st } \\
\text { Mezzanine Floor Level (On Steel Structure) }\end{array}$ & $5,618,483,000$ & $\begin{array}{c}\text { Change } \\
\text { Material } \\
\text { Specifications }\end{array}$ & Owner & Architecture \\
\hline 10 & $\begin{array}{c}\text { Entrance Mat (Dust Control) at BOH area, B6-B1Mezz } \\
\text { and 3-5 FL }\end{array}$ & $794,076,000$ & AddWorks & Owner & Architecture \\
\hline 11 & $\begin{array}{l}\text { Suspended Glass Partition to Entrance Hall at GF - 3rd } \\
\text { Floor Level }\end{array}$ & $11,352,169,719$ & $\begin{array}{c}\text { Change } \\
\text { Material } \\
\text { Specifications }\end{array}$ & Consultants & Architecture \\
\hline 12 & $\begin{array}{l}\text { Structural and Architectural Works for Bench at } \\
\text { Basement Area }\end{array}$ & $47,175,190$ & Add. Works & Owner & Architecture \\
\hline 13 & $\begin{array}{c}\text { Changes in the Location and Quantity of Fire Shutters in } \\
\text { Basement }\end{array}$ & $1,901,590,200$ & Design Change & Owner & Architecture \\
\hline 14 & Reduction in Depth of Lifts Pits & $163,569,305$ & Design Change & Consultants & Structure \\
\hline 15 & $\begin{array}{c}\text { RC stiffeners to Edge Beam / Cantiveler Slab at GL } 10 \text { / } \\
\text { BE at Mezanine Level to Level } 5\end{array}$ & $453,193,195$ & Design Change & Owner & Str \\
\hline 16 & $\begin{array}{l}\text { Changes in Beams to Air Shaft at Basement } 1 \text { Mezz at } \\
\text { GL } 1 / \text { AB }\end{array}$ & $23,033,533$ & Design Change & Owner & Structure \\
\hline 17 & $\begin{array}{c}\text { Changes inShafts and Beams to Pa nel Rooms at } \\
\text { Basement } 5 \text { - Basement } 1 \text { Mezz }\end{array}$ & $66,409,872$ & Design Change & Owner & Structure \\
\hline 18 & Revised Structural Layout Plan for Ground Floor & $196,643,655$ & Design Change & Owner & Structure \\
\hline 19 & $\begin{array}{c}\text { Revised layout of Locker Room and Shower Room at } \\
\text { Level B3 (Builder Works) }\end{array}$ & $(5,381,000)$ & Design Change & Owner & Architecture \\
\hline 20 & $\begin{array}{l}\text { Revised layout of Female Toilet, Janitor, and Pantry at } \\
\text { B1 } \\
\text { Level (Builder Works) }\end{array}$ & $51,369,000$ & $\begin{array}{l}\text { Design } \\
\text { Change }\end{array}$ & Owner & Architecture \\
\hline 21 & $\begin{array}{c}\text { omission of Beams at VIP and HZ Elevator Lobby on } \\
\text { Transfer Floor Level }\end{array}$ & $(15,842,106)$ & Design Change & Owner & Structure \\
\hline 22 & $\begin{array}{l}\text { Changes to Mid Zone Lift Motor Room at Level } 32 \\
\text { (Structure works) }\end{array}$ & $161,367,890$ & Design Change & Owner & Structure \\
\hline 23 & $\begin{array}{l}\text { Changes to Mid Zone Lift Motor Room at Level } 32 \\
\text { (Architecture works) }\end{array}$ & $(11,934,000)$ & $\begin{array}{l}\text { Design } \\
\text { Change }\end{array}$ & Owner & Architecture \\
\hline 24 & $\begin{array}{l}\text { RC Works for Revision to Service Lift Motor Room at } \\
\text { Level } 42 \text { ( MEP 2nd Floor) }\end{array}$ & $56,566,286$ & Design Change & Owner & Structure \\
\hline 25 & $\begin{array}{l}\text { Structural \& Architectural Works for the Revised } \\
\text { Parapet Walls of Podium Floor (Mezz to Level 7) }\end{array}$ & $971,076,910$ & Design Change & Owner & Structures \\
\hline
\end{tabular}


ISSN No:-2456-2165

\begin{tabular}{|c|c|c|c|c|c|}
\hline 26 & RC Structure in 7th Floor Level & $79,194,211$ & $\begin{array}{c}\text { Design } \\
\text { Change }\end{array}$ & Owner & Structure \\
\hline 27 & $\begin{array}{c}\text { Enlargement to Column at the Shear Wall on Level 19th } \\
\text { and 20 }\end{array}$ & $212,472,245$ & Design Change & Owner & Structure \\
\hline
\end{tabular}

\begin{tabular}{|c|c|c|c|c|c|}
\hline No. & Description & $\begin{array}{l}\text { Amount } \\
\text { (Rupiah) }\end{array}$ & $\begin{array}{l}\text { Causative } \\
\text { Factor }\end{array}$ & Instructed by & Scope of Work \\
\hline 28 & Design Changes to MEP Room Layout at Level 41 & $609,055,931$ & $\begin{array}{l}\text { Design } \\
\text { Change }\end{array}$ & Owner & Architecture \\
\hline 29 & Steel Stair P6, P7, P8 and P9 at 41st Floor Level & $274,903,710$ & Design Change & Owner & Structure \\
\hline 30 & Adjustments to LPG Room on Ground Floor - RC Works & $32,546,205$ & Add. Works & Owner & Structure \\
\hline 31 & $\begin{array}{c}\text { Adjustments to LPG Room on Ground Floor - } \\
\text { Architecture Works }\end{array}$ & $85,568,000$ & Add. Works & Owner & Architecture \\
\hline 32 & Dog House on Level 41 & $18,590,760$ & Add. Works & Owner & Structure \\
\hline 33 & $\begin{array}{c}\text { Revised Lightweight Brickwall Thickness to Typical Lift } \\
\text { Lobbies (LZ, MZ and HZ) }\end{array}$ & $206,099,000$ & Design Change & Owner & Architecture \\
\hline 34 & RC Slab to AHU Room at Lev 41 & $6,295,629$ & Design Change & Owner & Structure \\
\hline 35 & Topping Up of Inner Core Slab to Level 18 & $403,086,000$ & Add. Work & Owner & Structure \\
\hline 36 & $\begin{array}{l}\text { Peephole Door and Gutter Cover to Cavity Wall at } \\
\text { Basement } 06 \text { - Basement } 02\end{array}$ & $659,520,000$ & Design Change & Owner & Architecture \\
\hline 37 & \begin{tabular}{|c|} 
Structural Construction Drawing (For Con) of MEP floor \\
(level 6)
\end{tabular} & $437,614,576$ & Design Change & $\mathrm{Ow}$ & Str \\
\hline 38 & Thermal Insulation of Floors and Walls & $4,166,600,000$ & Design Change & Owner & Architecture \\
\hline 39 & coring Test to Floor Slab of Level 6 and 8 & $53,569,000$ & Add. Work & Consultants & Structure \\
\hline 40 & Typical Pantry sink and Cabinet & $676,100,479$ & Design Change & Owner & Architecture \\
\hline 41 & Dog Houses Type 5A and 5B on Level 42 & $39,714,770$ & Add. Works & Owner & Structure \\
\hline 42 & $\begin{array}{c}\text { Mobile Network Room on Level } 1 \text { Mezzanine and RRU } \\
\text { Room on Levels 6,9, 41and }\end{array}$ & $160,092,270$ & Design Change & Owner & Architecture \\
\hline 43 & Revised Retail and Mail Room on Basement 1 & $11,775,000$ & Design Change & Owner & Architecture \\
\hline 44 & Redundancy and Air Lock Rooms on Level 5 & $7,456,000$ & ChangeDesign & Owner & Architecture \\
\hline 45 & Unit Rates for homogenous and Ceramic tiles & $1,785,467,000$ & Prime cost rate & Owner & Architecture \\
\hline 46 & $\begin{array}{l}\text { Galvanized railing to around } 19 \text { th Floor Level } \\
\text { (External) }\end{array}$ & $255,200,000$ & Add. Works & Owner & Architecture \\
\hline 47 & Change in the Material of Louvres in $6 \mathrm{~F}$ to MEP Floor & $602,300,000$ & \begin{tabular}{|c|} 
Change \\
Material \\
Specifications
\end{tabular} & Owner & Architecture \\
\hline 48 & Revision to Fan Room at Basement 6 & $33,036,139$ & Design Change & Owner & Architecture \\
\hline 49 & $\begin{array}{c}\text { Roller Shutters in Ground Floor and Revision to Loading } \\
\text { / Unloading Area }\end{array}$ & $795,379,575$ & Add. Works & Owner & Architecture \\
\hline 50 & Waterproofing to Corridor on Level 2 & $300,525,000$ & Add. Works & Owner & Architecture \\
\hline 51 & Paint Materials for Core Wall and Car Park & $4,292,379,000$ & Add. Works & Owner & Architecture \\
\hline 52 & Roof Structure for Water Pump at Level 41 & $33,955,410$ & Add. Works & Owner & Structure \\
\hline 53 & Glass Door to the Banking Hall 2 at GF & $551,743,000$ & Design Change & Owner & Architecture \\
\hline
\end{tabular}

Table 1:- Summary of Variation Order

Based on data released in Table 1, it can be graphed the relationship between the number of orders per year variation in the type of work to figure out the type of work the most and the largest amount of variation orders for the year.

The results of data processing relationship between the amount of variation order with the type of work contained in the Project Office Building Sudirman Central Business District showed that the percentage of 51\% is the architectural work that is then followed by the work structure with a percentage of $49 \%$. 


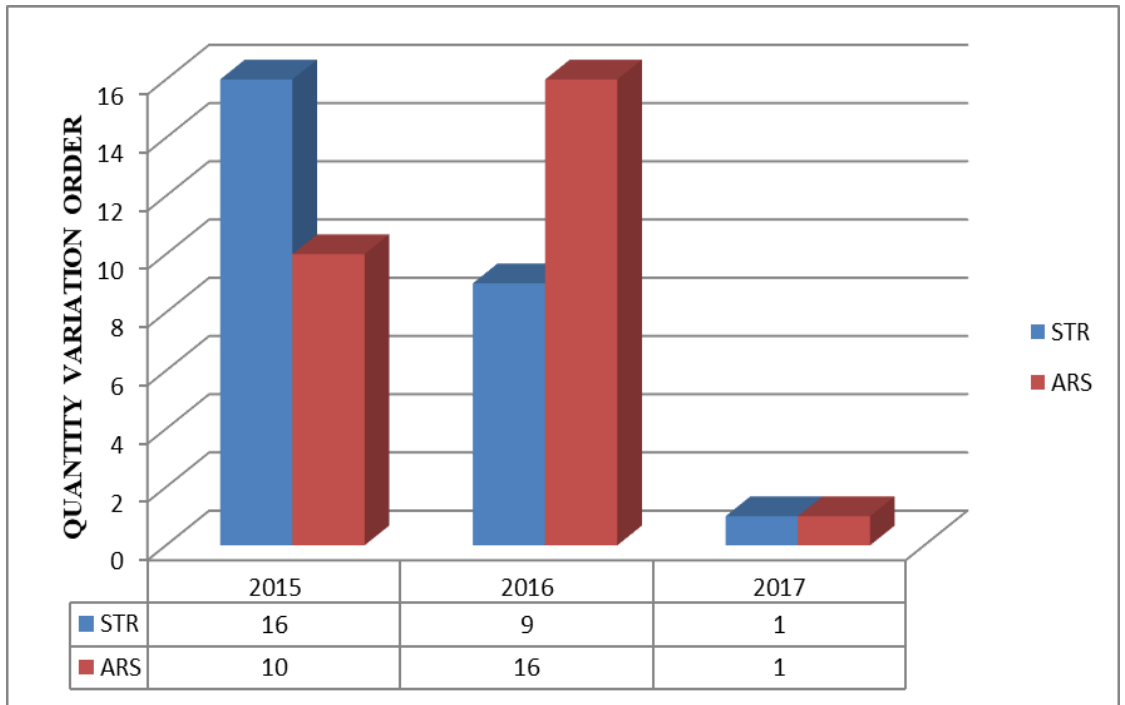

Chart 1:- Corelation Between Variation Orders per Year with Scope of Work

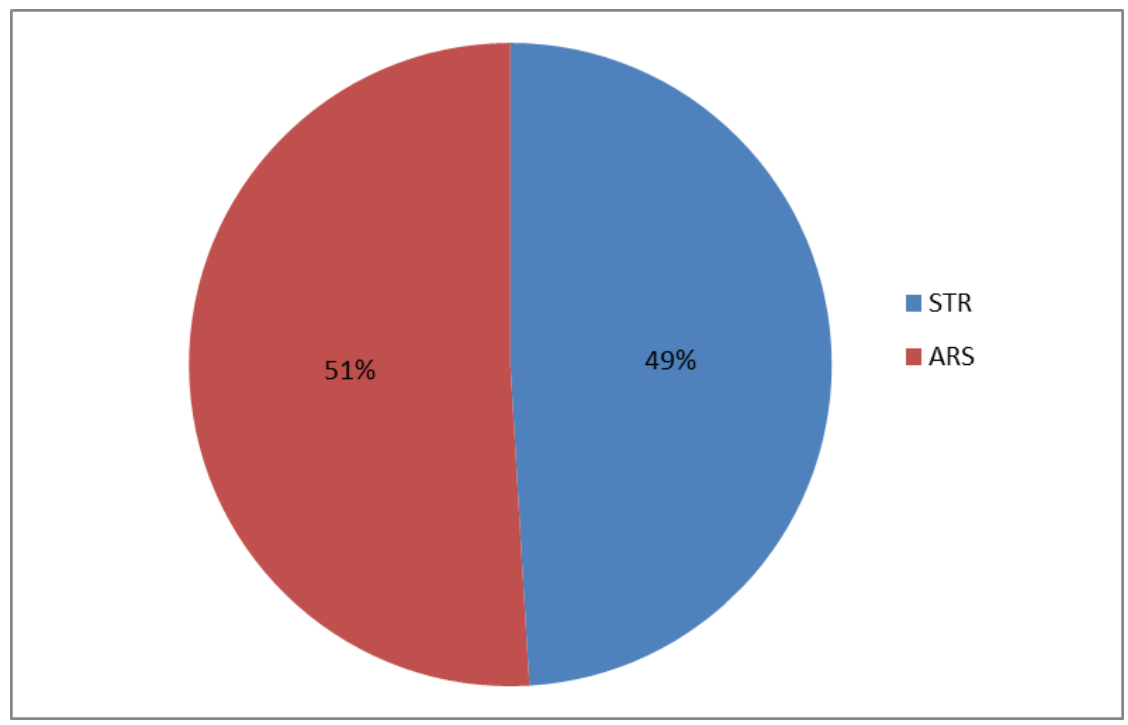

Chart 2:- Percentage of Total Variation Order by Scope of Work

Based on Table 1. recapitulation variation order on the Project Office Building Sudirman Central Business District, there are 53 items less additional work that can be divided into four by a contributing factor. These factors are:

- Additional Work

- Design Change

- Specification Material Change

- Prime Cost Rate

Of the four factors, can be analyzed which factors most likely to cause the onset of variation order. This analysis is as follows:

\section{Analysis of Causes Based on the amount of PMI}

Based Project Manager Instruction (PMI) issued in table 1 , it can be graphed the relationship between the causes of variation order by the number of PMI issued to find out what factors most likely to cause the onset of jobs variation order,

The results of data analysis the relationship between the number of Project Manager Instruction (PMI) with the causes of variation orders contained in the Project Office Building Sudirman Central Business District showed that the factors causing the most cause variation work order is a design change with a percentage of $60 \%$. While the causes of the most rarely cause variation order is the prime cost rate with a percentage of $2 \%$. 


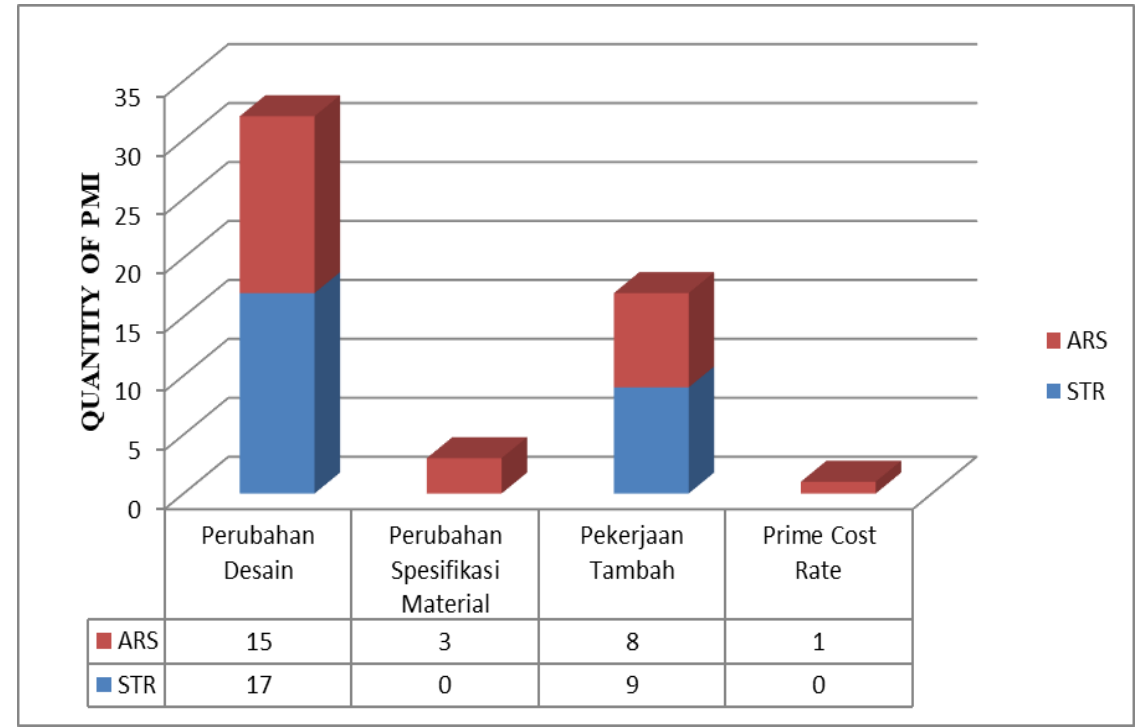

Chart 3:- Corelation between Causative Factors with Total PMI

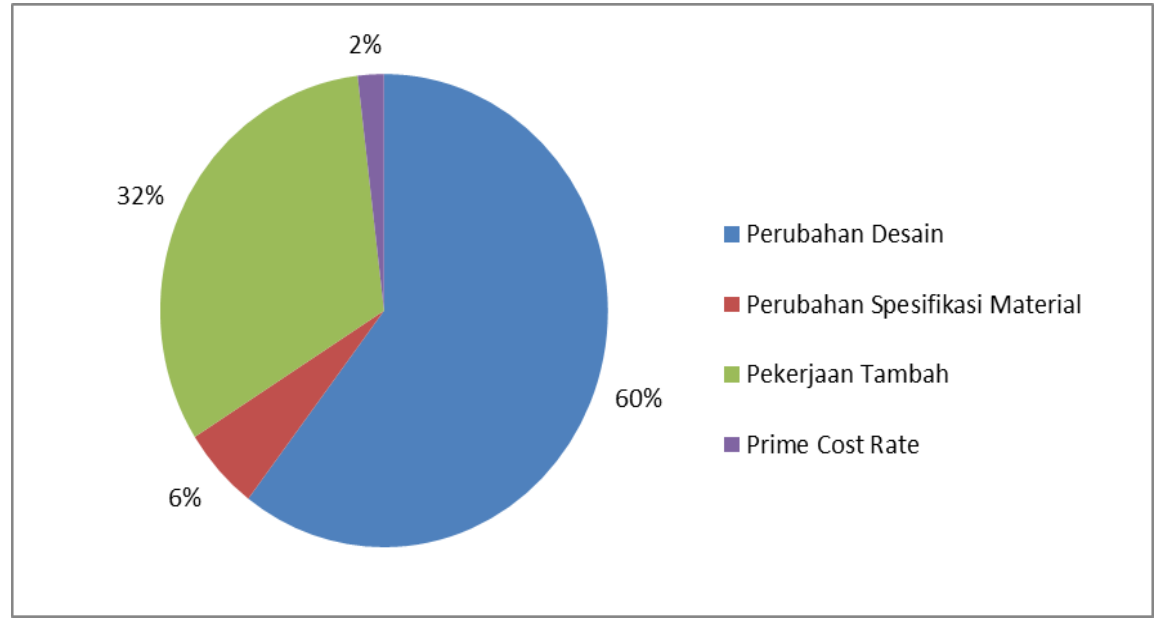

Chart 4:- Percentage Causative Factors of Variation Order by Total PMI

\section{Causes Analysis Based on Amount of Variation Order}

Based on the amount of variation order issued in Table 1 may be made recapitulation tables and graphs the relationship between a factor with amount of variation order to determine what is causing the greatest amount of variation orders and variation orders smallest amount.
The results of the data analysis of the relationship between the amount of the order variation caused by factors that cause variation orders contained in the Project Office Building Sudirman Central Business District showed that the factors that cause variation amount of the highest order is a design change to the percentage of $46 \%$. While the factors that cause variation amount of the low order is prime cost rate with the percentage of $3 \%$.

\begin{tabular}{|c|c|c|}
\hline No. & Causative Factor & Amount (Rupiah) \\
\hline 1 & Add. Works & $13,211,361,753$ \\
\hline 2 & Design Change & $27,758,978,698$ \\
\hline 3 & Specifications Material & $17,572,952,719$ \\
\hline 4 & Change & $1,785,467,000$ \\
\hline
\end{tabular}

Table 2:- Summary of Amount Variation order by Causative Factor 


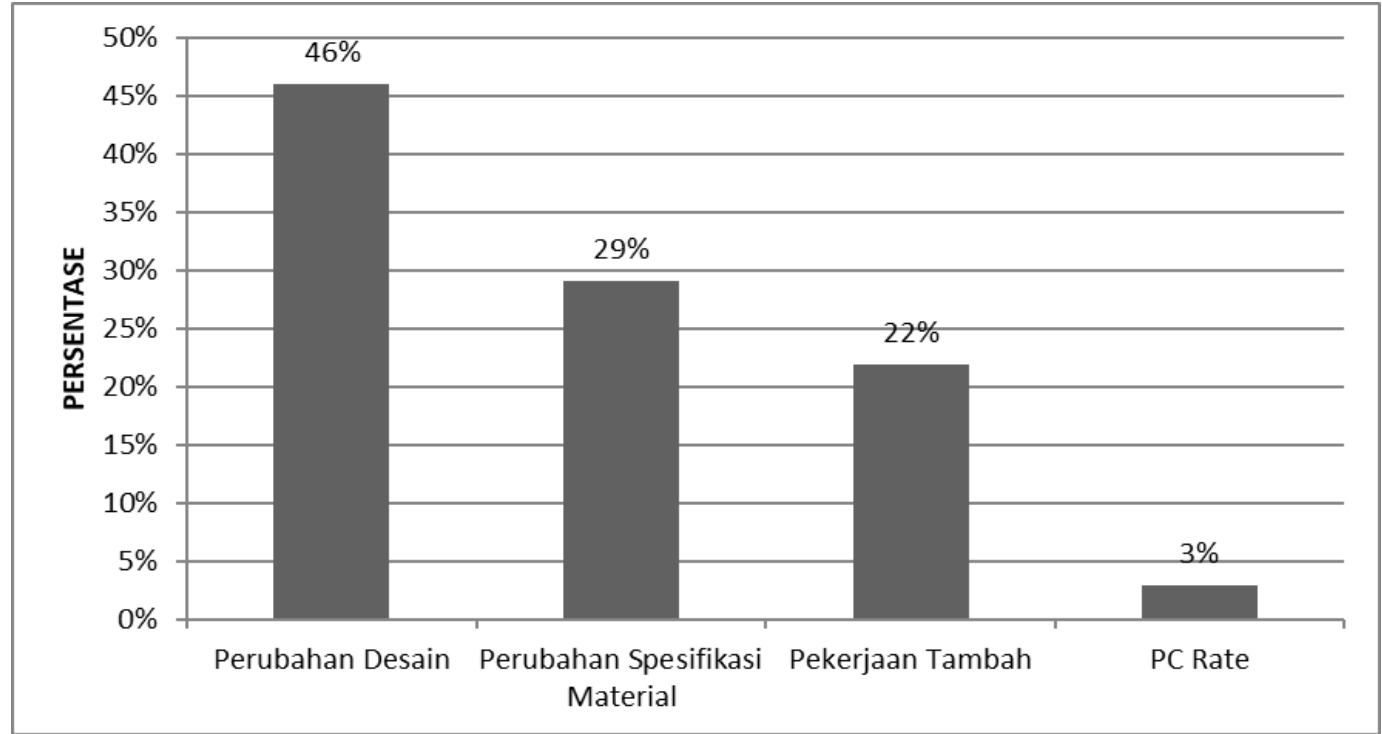

Graph 5:- Percentage of Causative Factor of Variation Order by Amount

In this study, the variation work orders have increased the impact of the implementation costs of the existing amount in the contract. Added costs can be analyzed by comparing the amount of a contract with a amount after the variation work order.

From the list of variation orders on the Project Office Building Sudirman Central Business District, it can be analyzed that the percentage increase costs as a result of variation work order is as follows:

Structural \& Architectural Contract Amount $=$ Rp. 1,187,701,101,231, -

Amount Cost Variation Order

$=$ Rp. 56,796,807,199, -

Amount Variation Order Cost Structure

= Rp. 19,796,041,781, -

Percentage of Variation Order Structure

$=($ Rp. 19,796,041,781 / IDR. 56,796,807,199)

$\mathrm{x} 100 \%=34.85 \%$

Variation Order Cost Amount Architecture

$=$ Rp. 37,000,765,418, -

Percentage of Variation Order Architecture

$=($ Rp. 37,000,765,418 / IDR. 56,796,807,199)

$\mathrm{x} 100 \%=65.15 \%$

Percentage of cost variation order to the amount of the contract structure and architecture

$=($ Rp. 56,796,807,199 / Rp. 1,187,701,101,231)

$\mathrm{x} 100 \%=4.78 \%$

\section{CONCLUSION}

After doing research on the causes of variation orders and the impact on the cost of the project implementation Office Building Sudirman Central Business District, it can be summed up as follows:

$>$ Based project Manager Instruction (PMI) jobs variation order is the largest is the work.

Factors causing the variation work order is additional work, change in design, material specification changes and prime cost rate. Based on the number of instructions issued, the most common cause factor causing variation work order is a design change.

Based on the research and analysis of the causes of variation orders and the impact on the cost of the implementation of the Project Office Building Sudirman Central Business District that has been done, there are some things that can be used as suggestions, as follows:

$>$ Planning the design and concept of the building should be planned well and perfect, so that the implementation can minimize any variation work order.

$>$ To perform the calculation of the budget plan at the beginning of the project should be done well ,, recording of data for identification of variation orders that compares employment data based on image, volume, technical specifications and materials.

$>$ Tim quantity surveyor must study the contract properly and carefully because in the contract consists of chapters and chapters which contain many rules on the implementation of the project. So it could be used as a reference and consideration for the manufacture of variation orders and conduct negotiations with the consultant quantity surveyor.

In the processes and stages in applications, calculations and rules in order variation agreement should be agreed in writing between the contractor and the consultant quantity surveyor and owner so far misunderstanding in the result agreements variation order. 


\section{REFERENCES}

[1]. Barrie, D. S., \& Paulson, B. C. (1992). Professional construction management. McGraw- Hill series in construction engineering and project management. New York: McGraw-Hill.

[2]. Fisk, E. R., \& Reynolds, W. D. (2006). Construction Project Administration. New Jersey: Pearson Prentice Hall.

[3]. Gilbreath, R. D. (1992). Managing Construction Contract Operational Control for Commercial Risk Second Edition. New York: John Wiley \& Sons Inc.

[4]. Sudrajat, E., \& Amin, M. (2017). Analysis of Variation order and Effect on Cost and Time at Highrise Building Project in Tangerang. Jurnal Teknik Sipil Universitas Mercu Buana, (1), 1-10. 